\title{
GERAKAN POLITIK GNPF-ULAMA DALAM PEMILIHAN UMUM PRESIDEN 2019
}

\section{Sandy Anugrah Tangkas ${ }^{1 *}$, Indiana Ngenget dan Musthofa ${ }^{2}$}

Institut Ilmu Sosial dan Ilmu Politik (IISIP) Jakarta, Indonesia ${ }^{1,2}$

udasandy.tangkas@gmail.com ${ }^{1 *}$,indiana.inge@gmail.com ${ }^{2}$, musthofamakhdor@gmail.com ${ }^{3}$

\begin{tabular}{l}
\hline \multicolumn{1}{c}{ Artikel info } \\
\hline Artikel history \\
Diterima : $28-12-2020$ \\
Direvisi : $16-01-2021$ \\
Disetujui : $20-01-2021$
\end{tabular}

Kata Kunci: gerakan politik islam; gnpf-ulama; pemilihan umum presiden 2019

Keywords: islamic political movement; gnpf-ulama; presidential election 2019

\begin{abstract}
Abstrak
Penelitian ini bertujuan untuk menjelaskan dan menganalisis bentuk-bentuk gerakan politik yang dilakukan GNPF-Ulama, pengaruh gerakan politik GNPF-Ulama, sikap dan pandangan-pandangan dari gerakan politik GNPFUlama terhadap kekalahan Prabowo Subianto dan Sandiaga Salahuddin Uno dalam dalam pilpres tahun 2019. Metode yang digunakan dalam penelitian ini adalah kualitatif dan deskriptif. Penelitian kualitatif didefinisikan sebagai suatu proses penyelidikan untuk memahami masalah sosial berdasarkan pada penciptaan gambaran holistik lengkap yang dibentuk dengan kata-kata, melaporkan pandangan informan secara terperinci dan disusun dalam latar alamiah. Hasil kesimpulan, secara empiris gerakan politik Islam GNPFUlama mengalami kegagalan karena kurang matangnya komunikasi dengan umat Islam dan kurang kuatnya basis massa Islam yang mendukung gagasan dan perjuangan politik GNPF-Ulama.
\end{abstract}

\begin{abstract}
This study aims to explain and analyze the forms of

political movements carried out by the GNPF-Ulama, the influence of the GNPF-Ulama political movement, the attitudes and views of the GNPFUlama political movement against the defeat of Prabowo Subianto and Sandiaga Salahuddin Uno in the presidential election. 2019. The methods used in this research are qualitative and descriptive. Qualitative research is defined as a process of investigation to understand social problems based on the creation of a complete holistic picture formed by words, reporting the views of informants in detail and arranged in a natural setting. The conclusion is that empirically the GNPF-Ulama Islamic political movement has failed due to inadequate communication with Muslims and the lack of a strong Islamic mass base that supports the ideas and political struggles of GNPFUlama.
\end{abstract}

Korespondence author: Sandy Anugrah Tangkas Email: udasandy.tangkas@gmail.com artikel dengan akses terbuka dibawah lisensi 


\section{Pendahuluan}

Indonesia adalah bangsa yang multikultural, dari segi budaya, etnis/ras dan religi, maka kekuatan Islam dalam perspektif politik dapat menjadi kajian yang menarik untuk ditelaah. Pasca reformasi kekuatan Islam dapat direpresentasikan dengan munculnya partai- partai Islam, yang dapat menjadi pilihan bagi masyarakat muslim di Indonesia. Secara umum dapat dikatakan bahwa masyarakat Indonesia merupakan representatif dari multikulturalisme dalam keragaman suku, ras, agama dan budaya, termasuk berbagai ras di dunia ada di Indonesia (Ngenget, n.d.). Oleh karena itu peristiwa dalam pemilihan umum presiden (Pilpres) tahun 2019 menjadi perhatian tersendiri bagi masyarakat di Indonesia, termasuk adanya gerakan politik Islam dari GNPF-Ulama.

Sebagai negara dengan jumlah penduduk penganut agama Islam terbesar di dunia, Indonesia berhasil menjadikan Islam dan demokrasi sebagai dua elemen penting yang tidak terpisahkan satu dengan yang lainnya. Hal ini mempunyai relevansi dengan posisi Indonesia sebagai negara dengan penduduk Islam terbesar di dunia, dengan jumlah pemeluk kurang lebih 222 juta jiwa (87\%) dari keseluruhan penduduk Indonesia yang berjumlah 260 juta (Sholikin, 2018).

Politik Indonesia kontemporer saat ini menunjukkan sebuah realitas menguatnya kebangkitan Islam politik, dalam bentuk populisme politik Islam. Populisme adalah pendekatan atau gerakan yang mengklaim/berbicara atas nama atau mewakili rakyat berhadapan dengan elite atau penguasa politik mapan. Ideologi populisme politik adalah pemihakan atau pembelaan pada massa rakyat yang selalu dikorbankan oleh elite politik atau rejim penguasa (Muhtadi, 2019).

Populisme politik di dunia Muslim, termasuk di Indonesia, sulit dielakkan dengan politik identitas Islam. Sehingga penggunaan istilah populisme Islam untuk menjelaskan fenomena politik sebagian kalangan umat Islam Indonesia merupakan eksistensi dari populisme politik dengan menekankan identitas Islam. Hal ini terkait dengan kenyataan bahwa mayoritas penduduk Indonesia adalah Muslim (Muhtadi, 2019).

Penyelenggaraan pemilihan umum di Indonesia pada tahun 2019, mengawali babak baru dalam sistem ketatanegaraan Indonesia, karena untuk pertama kalinya dalam sejarah, pemilihan umum dilaksanakan secara serentak, yakni memilih anggota legislatif sekaligus juga memilih presiden dan wakil presiden. Pemilihan umum pada tahun 2019, diwarnai dengan fasefase sebelumnya yang meliputi peristiwa-peristiwa sosial politik yang bersinggungan dengan sentimen identitas keagamaan dan peristiwa tersebut sangat bersejarah dan mempengaruhi perjalanan politik Indonesia.

Gerakan-gerakan sosial politik yang identik dengan nilai-nilai Islam dalam kontestasi politik di Indonesia dewasa ini, diantaranya bisa dilekatkan dengan gerakan politik Islam yang dilakukan oleh GNPF-Ulama dalam menyikapi pemilihan umum presiden (Pilpres) 2019

Sandy Anugrah Tangkas, Indiana Ngenget dan Musthofa.

Kelahiran GNPF-Ulama erat kaitannya dengan gerakan sosial politik yang identik dengan nilai-nilai Islam pada Pilkada DKI Jakarta 2017, yaitu berkaitan dengan peristiwa unjuk rasa yang dikenal dengan sebutan Aksi Bela Islam. Sebagai satu fenomena politik yang terjadi di Indonesia, Aksi Bela Islam merupakan sebuah wujud partisipasi publik dari masyarakat Indonesia atau civil Islam, karena dihadiri oleh umat Islam dari hampir seluruh wilayah Indonesia dengan mobilisasi massa yang massif dan militan.

Peristiwa Aksi Bela Islam yang dihadiri massa yang massif dan militan pada kasus menjelang dan sesudah Pilkada DKI Jakarta 2017 dinilai sangat mengejutkan, karena anggapan umum masyarakat Indonesia mengenai Islam, adalah sebuah agama yang mengajarkan toleransi terhadap umat agama lain, menghargai perbedaan-perbedaan, mencintai perdamaian, selaras dengan nilai-nilai dan budaya ketimuran Indonesia serta mempunyai relevansi dengan 
nilai-nilai demokrasi.

Dari sudut pandang politik, Aksi Bela Islam yang terjadi jelas bukan aksi demonstrasi biasa. Kehadiranya lebih sebagai gerakan sosial yang sarat dengan muatan ideologis, yang kemudian memantik diskursus ihwal bangkitnya gerakan Islam politik di Indonesia (Sholikin, 2018).

Politik identitas khususnya agama memang tidak pernah mati dalam arena politik di negeri ini. Momentum pemilihan Gubernur Jakarta dalam Pilkada DKI Jakarta 2017 adalah contoh nyata bagi pembenaran argumentasi tersebut. Ketika Identitas Agama muncul menjadi sebuah kekuatan politik dalam konteks politik Indonesia modern (Sari, 2016).

Dalam menyikapi pemilihan umum presiden 2019, Ketua GNPF-Ulama pertama Ustaz Bachtiar Nasir menjelaskan alasan perubahan nama dari GNPF-MUI menjadi GNPF- Ulama yaitu agar tidak membebani MUI dan semua hal yang dikawal GNPF berupa fatwa- fatwa, tidak semata-mata karena MUI. Sehingga istilah „Ulama ${ }^{e e}$ ini menjadi Ijtihad bersama dari tokoh-tokoh GNPF-Ulama bersama ulama-ulama yang ada dalam mengambil keputusa (Purnomo, 2019).

Momentum pemilihan umum presiden (Pilpres) 2019 dijadikan ruang bagi GNPFUlama untuk menyuarakan kembali kekecewaan terhadap presiden petahana, karena kebijakan-kebijakan pemerintah selama ini dianggap kerap melakukan pelemahan terhadap kekuatan Islam, dimana ada beberapa kasus ulama dan pemuka agama Islam dikenai kasuskasus hukum. Peristiwa tersebut dianggap oleh kalangan ulama sebagai upaya pelemahan terhadap kekuatan Islam, sehingga memunculkan sikap ketidakpercayaan dari para ulama terhadap pemerintah atas keadilan dan penegakkan hukum, yang semakin meneguhkan keyakinan ulama dan umat dengan menggelar berbagai unjuk rasa Aksi Bela Islam.

Pemilihan Umum Presiden (Pilpres) 2019, dijadikan momentum kembali oleh kelompok gerakan Islam yang telah berubah nama menjadi GNPF-Ulama untuk mengkritisi petahana dan memberikan dukungan politik kepada salah satu kandidat calon presiden dan wakil presiden lain. Berdasarkan masukan seluruh anggota yang berada dalam GNPF-Ulama akhirnya dilaksanakan Ijtima Ulama, yang isinya menjatuhkan pilihan dan memberikan dukungan kepada Ketua Umum Partai Gerakan Indonesia Raya (Gerindra) Prabowo Subianto sebagai calon presiden 2019-202, untuk bertarung melawan calon presiden petahana Joko Widodo.

Gerakan Politik GNPF-Ulama Dalam Pemilihan Umum Presiden 2019

Ijtima Ulama I yang dilangsungkan pada tanggal 27-29 Juli 2018, diselenggarakan oleh GNPF-Ulama untuk memberikan rekomendasi tentang kriteria khusus mengenai calon wakil presiden pendamping Prabowo Subianto untuk maju dan bertarung dalam pilpres tahun 2019. Kriteria khusus yang diajukan oleh GNPF-Ulama tersebut salah satunya adalah tokoh yang memiliki latar belakang agama, sebagai pendamping calon presiden Prabowo Subianto yang memiliki latar belakang seorang militer dan nasionalis.

GNPF-Ulama memunculkan dua nama tokoh nasional yang memiliki latar belakang agama, yaitu mantan Duta Besar Republik Indonesia untuk Kerajaan Arab Saudi dan Kesultanan Oman, sekaligus mantan Menteri Sosial Republik Indonesia, yang sedang menjabat sebagai Ketua Majelis Syuro Partai Keadilan Sejahtera, Salim Segaf Al Jufri, dan seorang ulama yang pada saat berjalannya proses-proses politik tahun 2019 tersebut sedang dalam trend popularitas yang tinggi, yaitu Ustaz Abdul Somad Batubara.

Dengan pertimbangan yang matang atas dua nama pilihan calon wakil presiden yang direkomendasikan oleh GNPF-Ulama dalam Ijtima Ulama I, Prabowo Subianto pada akhirnya memutuskan untuk memilih Sandiaga Salahuddin Uno kader Partai Gerakan Indonesia Raya, yang sedang menjabat sebagai wakil gubernur provinsi DKI Jakarta, untuk menjadi 
pendampingnya dalam pilpres tahun 2019.

GNPF-Ulama menggelar Ijtima Ulama II pada 16 September 2018, untuk memutuskan dukungan politik kepada pasangan calon presiden Prabowo Subianto dan calon wakil presiden Sandiaga Salahuddin Uno. Ijtima Ulama II juga mendorong untuk dibentuknya sebuah koalisi yang dinamakan sebagai Koalisi Keumatan yang terdiri dari Partai Gerakan Indonesia Raya (Partai Gerindra), Partai Amanat Nasional (PAN), Partai Keadilan Sejahtera (PKS) dan Partai Bulan Bintang (PBB).

Pada kesempatan tersebut, Prabowo Subianto menandatangani 17 poin kesepakatan yang tertuang dalam Pakta Integritas. Pakta Integritas tersebut merupakan hasil dari Ijtima Ulama II dengan disaksikan pula oleh tokoh-tokoh nasional diantaranya Ketua Umum Partai Amanat Nasional Zulkifli Hasan, Sekretaris Jenderal Partai Keadilan Sejahtera Mustafa Kamal dan Wakil Ketua Umum Partai Gerakan Indonesia Raya Fadli Zon. Hadir pula Ketua Umum PA 212, Ustaz Slamet Ma"earif, Sekretaris Jenderal FUI Ustaz Muhammad Al Khathath, dan Sekretaris Umum FPI, Munarman (Tim CNN Indonesia, 2018)

Secara khusus dukungan Ijtima Ulama II kepada pasangan Prabowo Subianto dan Sandiaga Salahuddin Uno mengukuhkan branding Ulama-Umara pada pasangan itu. Karena itu, Ulama-Umara merupakan representasi dari tokoh nasionalis dan religius yang bisa membawa bangsa lebih maju. Untuk mengakomodasi narasi besar ini, Ijtima Ulama menjadi penting, karena pasca Pilkada DKI Jakarta 2017, kekuatan politik Islam mendapatkan ruang yang besar dalam demokrasi di Indonesia. Menguatnya politik Identitas Islam merupakan representatif dari kebangkitan Islam sebagai kekuatan politik yang real dalam perpolitikan Indonesia modern (Tansal, 2019).

Gerakan politik yang diperjuangkan oleh GNPF-Ulama tercermin aktif pada kesolidan ulama-ulama dalam mengkonsolidasikan kepentingan umat dan puncaknya ikut berkampanye secara aktif pada pemilihan umum presiden dan wakil presiden (Pilpres) tahun 2019. Ijtima Ulama sebagai wujud aspirasi umat mengandung pencerahan politik yang mendambakan sebuah pemerintahan yang menjunjung tinggi hak asasi manusia serta menegakkan keadilan bagi seluruh lapisan golongan masyarakat Indonesia tanpa terkecuali.

Sandy Anugrah Tangkas, Indiana Ngenget dan Musthofa

Seluruh rangkaian aksi dan kegiatan-kegiatan serta sikap-sikap dan pandanganpandangan politik yang diperjuangkan oleh GNPF-Ulama, menjadi modal penting dalam rangka mendukung pasangan calon, serta menjadi satu hal yang tidak terpisahkan, dan menjadi satu hal yang berpengaruh terhadap perjalanan pasangan Prabowo Subianto dan Sandiaga Salahuddin Uno dalam kontestasi politik nasional melalui pemilihan umum yang diselenggarakan secara demokratis.

Berkaitan dengan masalah gerakan politik GNPF-Ulama dalam Pemilihan Umum Presiden tahun 2019 ada tinjauan literatur terdahulu yang mempunyai sedikit relevansi dalam perspektif filsafat yaitu: 1) Dian Dwi Jayanto dengan judul "Mempertimbangkan Fenomena Populisme Islam di Indonesia dalam Perspektif Pertarungan Diskusif: Kontestasi Wacana Politik Antara Gerakan Nasional Pengawal Ulama (GNPF) dan Nahdlatul Ulama (NU). Artikel ini menjelaskan bahwa GNPF-Ulama bukan menjadi kekuatan tunggal dalam mewakili aspirasi politik umat Muslim di Indonesia hari ini, sebagaimana unit analisis mainstream ketika mendiskusikan fenomena populisme Islam di Indonesia. Terdapat Nahdlatul Ulama (NU) yang memainkan peran penting dalam upaya menantang dan bahkan ingin merebut kembali wacana populisme Islam dari GNPF-Ulama. Upaya NU untuk meneguhkan diri sebagai kekuatan politik Islam tidak lepas dari kebangkitan gerakan Bela Islam yang telah mereduksi pengaruh NU sebagai organisasi Islam yang dominan di Indonesia. Di sisi lain, populisme berbasis identitas keagamaan Islam kerap dipahami sebagai salah satu model populisme yang 
berlawanan dengan kekuatan populisme berbasis nasionalisme. Padahal, upaya menyatukan ide nasionalisme dan Islam telah menjadi narasi agenda populisme bagi NU guna melawan narasi wacana GNPF-Ulama. Terlepas dari perbedaan ideologi keagamaan, perbincangan tentang populisme Islam di Indonesia tidak terlepas dari persoalan pertarungan wacana yang terjadi di dalam internal kekuatan kelompok Islam itu sendiri (Jayanto, 2019).

Mengacu pada literatur di atas, analisis mengenai Gerakan Politik GNPF-Ulama dalam Pemilihan Umum Presiden 2019 dari perspektif politik masih sangat sedikit. Disini letak pembeda dan signifikansi dari penelitian ini.

Penelitian ini berlandaskan pada rumusan masalah dalam bentuk pertanyaan mengenai latar belakang terbentuknya gerakan politik Islam GNPF-Ulama; bentuk-bentuk gerakan politik yang dilakukan oleh GNPF-Ulama dalam rangka mendukung Prabowo Subianto dan Sandiaga Salahuddin Uno dalam pilpres tahun 2019; pengaruh gerakan politik dari GNPFUlama dalam mendukung Prabowo Subianto dan Sandiaga Salahuddin Uno dalam pilpres tahun 2019; sikap dan pandangan-pandangan dari gerakan politik GNPF-Ulama terhadap kekalahan Prabowo Subianto dan Sandiaga Salahuddin Uno dalam dalam pilpres tahun 2019. Secara khusus tujuan makalah ini adalah menjelaskan dan menganalisis bentuk- bentuk gerakan politik yang dilakukan GNPF-Ulama, pengaruh gerakan politik GNPF- Ulama, sikap dan pandangan-pandangan dari gerakan politik GNPF-Ulama terhadap kekalahan Prabowo Subianto dan Sandiaga Salahuddin Uno dalam dalam pilpres tahun 2019.

\section{Metode Penelitian}

Penelitian ilmiah merupakan cara yang tepat untuk memecahkan masalah sosial karena merupakan penyelidikan yang sistematis, terkontrol, empiris, dan kritis tentang fenomenaGerakan Politik GNPF-Ulama Dalam Pemilihan Umum Presiden 2019

fenomena alami dengan dipandu oleh teori dan hipotesis-hipotesis tentang hubungan yang diduga terdapat antara fenomena-fenomena tersebut (Walidin \& Idris, 2015).

Pendekatan yang digunakan dalam penelitian ini adalah kualitatif dan deskriptif. Penelitian kualitatif didefinisikan sebagai suatu proses penyelidikan untuk memahami masalah sosial berdasarkan pada penciptaan gambaran holistik lengkap yang dibentuk dengan kata-kata, melaporkan pandangan informan secara terperinci dan disusun dalam latar alamiah (Creswell \& Creswell, 2017). Menurut Keith Punch (2006), qualitative research is empirical research where the data are not in the form of number. Model karakteristik penelitian kualitatif akan sangat memudahkan peneliti dalam menemukan dan memahami pertanyaan penelitian. Seperti yang disebutkan oleh (Creswell \& Creswell, 2017), dimana peneliti dapat menggunakan multiple methods that are interactive and humanistic. Metode pengumpulan data berkembang seiring dengan meningkatnya jumlah partisipan dan sensitivitas yang terlibat dalam penelitian ini.

Penelitian ini dilakukan dengan menggunakan tipe penelitian deskriptif explanatory yang merupakan kombinasi antara penelitian deskriptif dan penelitian explanatory. Penjelasannya, penelitian deskriptif ditujukan untuk menjawab pertanyaan, ,apa ${ }^{\text {ee }}$, sementara penelitian eksplanasi akan menjawab pertanyaan ,mengapa ${ }^{\text {ee }}$ dan „bagaimana ${ }^{\text {ee }}$.

Desain penelitian ini dimulai dengan tahap pengumpulan data mengenai latar belakang terbentuknya gerakan politik Islam GNPF-Ulama; bentuk-bentuk gerakan politik yang dilakukan oleh GNPF-Ulama, pengaruh gerakan politik dari GNPF-Ulama dalam mendukung Prabowo Subianto dan Sandiaga Salahuddin Uno dalam pilpres tahun 2019; sikap dan pandangan-pandangan dari gerakan politik GNPF-Ulama terhadap kekalahan Prabowo Subianto dan Sandiaga Salahuddin Uno dalam dalam pilpres tahun 2019.

Teknik pengumpulan data dalam penelitian ini mengacu pada teknik wawancara (deep 
interview) dan studi pustaka (library Research), berbagai literatur tertulis digunakan sebagai data dalam memperkuat hasil wawancara, seperti berbagai buku/literatur, jurnal dan pemberitaan media massa yang relevan dengan masalah dan tujuan penelitian.

Data hasil wawancara mendalam (indept interview) sebagai data utama diperkuat dengan studi pustaka akan saling melengkapi, mengkontrol serta mengkonfirmasi antara satu dengan lainnya. Data keseluruhan akan disajikan berupa rancangan analisis berbentuk narasi yang dilengkapi dengan deretan dan kolom sebuah matriks untuk data kuantitatif seperti tabel, grafik, diagram dan sebagainya. Melalui penyajian data tersebut, maka data terorganisasikan, tersusun dalam pola hubungan, sehingga akan lebih mudah dipahami (Sugiyono, 2012).

\section{Hasil dan Pembahasan}

Mengacu pada tujuan penulisan maka akan dibahas mengenai latar belakang terbentuknya gerakan politik Islam GNPF-Ulama; bentuk-bentuk gerakan politik yang dilakukan oleh GNPF-Ulama dalam rangka mendukung Prabowo Subianto dan Sandiaga Salahuddin Uno dalam pilpres tahun 2019.Kemudian menganalisis pengaruh gerakan politik dari GNPF-Ulama dalam mendukung Prabowo Subianto dan Sandiaga Salahuddin Uno dalam pilpres tahun 2019; dan terakhir menganalisis sikap dan pandangan-pandangan dari gerakan politik GNPF-Ulama terhadap kekalahan Prabowo Subianto dan Sandiaga Salahuddin Uno dalam dalam pilpres tahun 2019.

\section{Latar Belakang Gerakan Politik GNPF-Ulama}

Gerakan Nasional Pengawal Fatwa Ulama atau yang populer dengan nama GNPFUlama pada awalnya bernama Gerakan Nasional Pengawal Fatwa Majelis Ulama Indonesia atau yang dikenal dengan sebutan GNPF-MUI. Gerakan tersebut dihimpun dengan cara menggalang kekuatan umat dan ulama dengan tujuan untuk mempersatukan seluruh umat Islam demi kepentingan bangsa dan negara yang luas, mencakup hal-hal seperti keadilan sosial.

Beberapa tokoh-tokoh dari kalangan ulama dan pemuka agama Islam Indonesia memiliki gagasan tentang dibentuknya GNPF-Ulama, yang diharapkan dapat menjadi sebuah organisasi yang dapat mewadahi kepentingan umat secara luas. Tokoh-tokoh Islam yang menjadi inisiator dibentuknya GNPF-Ulama, salah satunya adalah Habib Muhammad Rizieq Shihab. GNPFUlama yang sebelumnya bernama GNPF-MUI, dikenal sangat dekat dengan sosok Habib Rizieq Shihab. Selain sebagai salah satu inisiator pembentukan organisasi GNPF-Ulama, tokoh ini juga menjabat sebagai Ketua Dewan Pembina dari GNPF-Ulama. Habib Rizieq Shihab dalam posisinya tersebut, memiliki pengaruh yang sangat kuat dalam menggerakkan seluruh rangkaian kegiatan-kegiatan yang dijalankan oleh GNPF-Ulama.

Gerakan-gerakan politik GNPF-Ulama merupakan kelanjutan dari gerakan perjuangan dan semangat awal dibentuknya organisasi ini, yaitu sebagai wadah perjuangan untuk hal-hal mengenai persoalan keadilan dalam masyarakat. Perbedaannya terletak pada fokus utama gerakan, jika GNPF-MUI pada awalnya, hanya difokuskan terhadap kasus penegakkan keadilan kasus penistaaan agama, sedangkan GNPF-Ulama, memiliki fokus terhadap persoalan bangsa dan negara yang lebih luas lagi.

Setelah mengubah namanya menjadi GNPF-Ulama, organisasi tersebut lebih leluasa dalam bergerak dan melancarkan aksi-aksinya demi mengawal kepentingan umat, khususnya dalam kasus hukum yang banyak menyeret ulama dan kelompok Islam lainnya. Mereka terus berjuang dalam hal-hal tersebut dengan menggalang kekuatan umat, dengan menggelar rangkaian aksi-aksi demonstrasi yang dimaksudkan untuk menyatukan kepentingan umat yang lebih besar. Aksi tersebut dikenal dengan nama Aksi Bela Islam.

Berdasarkan keberhasilan gerakan sebelumnya, dalam pemilihan kepala daerah DKI Jakarta tahun 2017, yang menjadi salah satu keberhasilan populisme Islam dalam politik Indonesia, dengan sukses menghantarkan kandidat tertentu yang menjadi pilihan ulama menjadi kepala daerah. GNPF-Ulama memandang perlu ada perubahan yang lebih luas lagi 
untuk dapat mewujudkan cita-cita yang lebih besar lagi, yaitu berjuang untuk mendukung salah satu kandidat pada pilpres tahun 2019, karena GNPF-Ulama memandang momentum kesuksesan pada pilkada DKI Jakarta dapat ditingkatkan pada level politik nasional (Purnomo, 2019).

Gerakan politik Islam GNPF-Ulama merupakan fenomena kebangkitan Islam Politik atau populisme Islam dalam kehidupan sosial politik masyarakat Indonesia, sejak terjadinya sejumlah aksi massa kalangan Muslim Indonesia pada akhir 2016 dan awal 2017 terkait dengan Pilkada DKI Jakarta 2017 (Muhtadi, 2019). Beberapa faktor melatarbelakangi kemunculan gerakan politik Islam, yang awalnya bernama GNPF-MUI tersebut, dan faktor- faktor tersebut menjadi kuat dan memiliki alasan yang relevan melihat kondisi sosial politik yang berkembang saat itu.

kasus Pilkada DKI Jakarta tahun 2017. Gerakan aksi bela Islam adalah gerakan politik civil Islam yang berkembang dari adanya ketidakpuasan dari umat Islam terhadap masalah penistaan agama yang dilakukan Ahok dalam pidatonya di kepulauan Seribu. Kasus ini dianggap berbeda dengan kasus sejenis yang langsung diproses secara hukum, adanya perlakuan yang berbeda ini yang menjadikan umat Islam melakukan aksi secara bergelombang di akhir tahun 2016 dan awal tahun 2017 (Abdullah, 2018).

Hadirnya GNPF-Ulama, pada dasarnya dilatarbelakangi persoalan ketidakadilan yang dirasakan oleh umat dan ulama. Ketidakadilan tersebut memunculkan sebuah tekad dan keyakinan para ulama untuk membentuk sebuah wadah yang diharapkan dapat menjaga persatuan di antara umat Islam dalam menghadapi situasi dan kondisi sosial politik negara saat itu. Keberadaan GNPF-Ulama, juga dipandang sebagai simbol perjuangan umat dalam menegakkan kebenaran dan keadilan yang mereka anggap sangat jauh dari fakta yang terjadi di lapangan terkait dengan kasus Ahok tersebut (Purnomo, 2019).

Kedua, munculnya berbagai keresahan yang sudah memuncak terhadap adanya prosesproses hukum yang dialamatkan kepada ulama-ulama dan kepada kalangan pemuka agama Islam. Hampir dari setiap tokoh-tokoh dari berbagai ormas-ormas Islam mendesak agar para kyai, untuk mengambil satu sikap yang konkret, yang sanggup untuk menghadirkan kepastian dalam kasus kriminalisasi ulama dengan menggelar audiensi-audiensi dengan berbagai pihak yang berwenang seperti kepolisian, dan juga dengan ormas-ormas Islam.

Unjuk rasa Aksi Bela Islam itu berawal dari Habib Rizieq, yang digagas dan didiskusikan dengan maksud sebagai sebuah gerakan menuntut keadilan, menentang kriminalisasi ulama dan menuntut agar pemerintah menjalankan roda pemerintahan dengan seadil-adilnya, demi terciptanya kebaikan dan kemaslahatan umat. Pada saat itu, GNPF-MUI juga melakukan beberapa pertemuan terhadap pihak-pihak yang terkait untuk membicarakan hal-hal menyangkut perkembangan kasus hukum yang menyeret para ulama. Menurut Ketua Umum Persaudaraan Alumni 212 (PA 212), gerakan spirit 212 perlu dipertahankan untuk mengakomodir alumni yang jumlahnya besar, agar dapat melakukan konsolidasi dalam sebuah wadah gerakan moral dan gerakan lapangan (Maarif \& Matin, 2019).

Menurut GNPF-Ulama dan kelompok PA 212, tuduhan kriminalisasi ulama kepada pihak pemerintah dan pihak kepolisian cukup beralasan. Beberapa ulama dan tokoh Islam, baik dari pihak GNPF-Ulama maupun yang lain, seperti K. H Muhammad Sobri Lubis yang terseret kasus dugaan makar, K. H Bachtiar Nasir dalam kasus pencucian uang, serta Ustaz Muhammad Slamet Mae arif menjadi tersangka dalam kasus kampanye terselubung, dan hal lainnya yang membuat kalangan ulama, khususnya pihak GNPF-Ulama merasa disudutkan. Hal-hal yang demikian, mereka anggap sebagai bagian dari upaya untuk mereduksi kelompok-kelompok Islam sangat kritis terhadap pemerintah (Maarif \& Matin, 2019).

Dengan mengambil posisi yang berseberangan dengan pemerintah dalam banyak hal, termasuk pandangan-pandangan politik, juga disertai sikap kritis terhadap beberapa kebijakan pemerintah yang bertentangan dengan nilai-nilai dan syariat Islam, GNPF-Ulama memiliki 
harapan dan keinginan agar Indonesia dapat memperoleh sosok pemimpin nasional yang jauh lebih baik dari yang sebelumnya. Untuk memenuhi harapan dan keinginan umat serta ulamaulama dan tokoh nasional yang menjadi bagian dari GNPF-Ulama, kemudian berinisiatif menggelar serangkaian diskusi politik keagamaan yang disebut Ijtima Ulama (Purnomo, 2019).

\section{Gerakan Politik Islam GNPF-Ulama dalam Pilpres 2019}

Secara khusus gerakan politik GNPF-Ulama dapat diklasifikasikan sebagai kelompok Kepentingan Non Asosiasional. GNPF-Ulama merupakan kelompok yang dalam melakukan kegiatan dan menyampaikan kepentingannya hanya dalam momentum tertentu saja. Kelompok ini tumbuh berdasarkan solidaritas yang sama, yaitu agama dan dalam menyampaikan kepentingannya melalui tokoh atau pemimpin-pemimpin agama, dan organisasi ini tidak terlalu aktif secara politik.

Gerakan politik merupakan gerakan sosial kemasyarakatan yang bergerak dalam bidang politik, dalam hal ini mencakup persoalan akumulasi dari solidaritas dan keprihatinan bersama dari sebagian golongan masyarakat yaitu kelompok Islam. Gerakan politik lebih mendasarkan kepada persamaaan akan kesatuan sikap dan pandangan politik untuk tujuan dan fokus masalah tertentu.

Teori gerakan sosial memberikan upaya memahami berbagai gejala Islam politik secara lintas-disiplin. Ia meneropong tidak saja dinamika kesejarahan, tapi juga proses dan organisasi aktivisme yang mengusung bendera Islam. Ia sekaligus memberikan pemahaman bagaimana dinamika, proses dan organisasi aktivisme keislaman itu dapat dipahami sebagai unsur penentu terjadinya aksi kolektif, yang bekerja melampaui keunikan Islam sebagai sistem makna, identitas, dan basis aksi kolektif. Meski warna ideologis membedakan aktivisme keislaman dalam beberapa hal dari aksi-aksi kolektif lainnya yang berorientasi sekular. Sehingga dapat dikatakan gerakan sosial Islam adalah rasional dan muncul karena persentuhannya dengan dinamika politik tertentu, melalui proses mobilisasi yang melibatkan jaringan-jaringan rekruitmen yang rumit dan dipoles dengan sentuhan-sentuhan ideologi melalui framing yang tepat (Hasan, 2007).

Islam politik sebenarnya merupakan gejala politik keagamaan yang tidak bisa dipisahkan dari konteks power struggle. Di dalamnya terjadi sinkretisme antara politik dan agama. Motifmotif politik yang berupaya menempatkan Islam dalam lingkar kekuasaan negara, sebagai sistem yang mengatur semua aspek kehidupan, termasuk norma hukum, sosial-budaya, sistem ekonomi, stagnasi sosial dan tata hubungan internasional, mendapatkan legitimasinya dalam bahasa-bahasa agama (Hasan, 2007).

Islam dan realitas sosio-historis para pemeluknya terutama dalam menghadapi perubahan-perubahan sosial yang masuk ke dalam gerakan-gerakan keagamaan. Gerakan agama selalu mengenai masalah kebenaran dari doktrin atau ajaran yang sedang dianut, yang menyangkut penghayatan kultural tentang bagaimana sesungguhnya sesuatu yang diyakini itu terpancar dalam kehidupan pribadi dan kenyataan sosial. Gerakan agama di lingkungan umat Islam, yang disebut gerakan Islam, tidak lepas bahkan tampak kental menunjukkan pergumulan antara doktrin ajaran dengan realitas kehidupan para pemeluknya (Jamaan \& Wijaksono, 2014).

Ketika politik dihubungkan dengan akhlak (agama), sebagaimana yang sudah menjadi tradisi para ilmuwan Muslim, maka politik harus diarahkan kepada pembelajaran edukasi, mensucikan diri, dan menjadi bimbingan (al-ta'lim, al-tahzib, wa al-irsyad). Oleh karena itu, politik menurut Al-Ghazali menduduki posisi yang tinggi dan istimewa (mumtaz). Oleh karenanya, menurut Al-Ghazali tidak akan tercipta keteraturan dalam beragama, jika ada keteraturan dalam politik, karena sesungguhnya dunia adalah tempat menanam (mazra'ah) untuk akhirat (Aly, 2018).

Dalam praktik ketatanegaraan masa kini, hubungan antara agama dan negara dapat diklasifikasikan ke dalam tiga bentuk, yakni yang pertama adalah Integrated yaitu penyatuan 
antara agama dan negara, yang kedua adalah Intersectional yaitu persinggungan antara agama dan negara, dan yang ketiga adalah Sekularistik yaitu pemisahan antara agama dan Negara (Abdillah, 2013).

Namun dalam kenyataannya, umat Islam tetap memperhatikan faktor agama dalam kehidupan berbangsa dan bernegara. Hal ini sebenarnya tidak terlepas dari karakteristik ajaran Islam itu sendiri, yang tidak hanya merupakan sistem teologis, tetapi juga cara hidup yang berisi standar etika moral dan norma-norma dalam kehidupan masyarakat dan Negara (Abdillah, 2013).

Pada tingkat masyarakat, agama harus memperkuat unsur-unsur non-agama dalam masyarakat, yaitu civil society dan civil society pada gilirannya harus memperkuat keterlibatan politik. Keterlibatan politik mendorong partisipasi politik yang diharapkan dapat memperkuat dukungan pada sistem demokrasi (Mujani, 2007).

Islam di Indonesia membantu kaum Muslim untuk lebih terlibat dalam perkumpulan kewargaan, terlibat dalam politik, dan karenanya menjadi terintegrasikan ke dalam sistem. Islam kongruen dengan kedua unsur demokrasi tersebut, perkumpulan dan keterlibatan, yang mengintegrasikan kaum Muslim secara keseluruhan. Islam membantu mereka untuk terlibat dalam praktik demokrasi, yakni dalam partisipasi politik (Mayrudin, 2018).

Menurut jalan pemikiran Ibnu Taimiyah, integrasi politik dan agama adalah menyatunya politik dan agama dalam satu lembaga negara. Oleh karenanya, politik dan agama tidak terbagi menjadi dua lembaga terpisah, di mana politik menjadi urusan publik mengurusi keduniaan dan agama di posisikan untuk mengurusi hal-hal yang yang bersifat privat. Atas dasar hal ini, maka semua aktivitas perpolitikan didasarkan pada agama dalam arti agama menjadi dasar bagi semua kebijakan-kebijakanstrategis Negara (Aly, 2018).

Pandangan Buya Syafii Maeearif tentang pola hubungan antara negara dan agama secara garis besar adalah bukan semata-mata sebagai ritual peribadatan saja tetapi lebih dari itu, Islam menyangkut hal-hal tentang kaidah-kaidah dan batas-batas dalam bersosial dalam masyarakat. Dalam hal ini, ia sepakat dengan pandangan Ibnu Taimiyah dalam kitab As- Siyasi AsSyar'iyyah yang mengemukakan bahwa negara merupakan sesuatu yang penting bagi agama, tanpa adanya negara, agama tidak akan tegak dengan kokoh. Hal itu tidak mungkin terealisasi tanpa kekuasaan (Asroni, 2011).

Dengan demikian baik dalam konsep ketatanegaaran maupun realitas pada saat ini, hubungan antara agama dan negara di Indonesia tetap dalam bentuk yang kedua, hubungan persinggungan antara agama dan negara, yang berarti tidak sepenuhnya terintegrasi dan tidak sepenuhnya terpisah. Dalam hubungan semacam ini, terdapat aspek-aspek kenegaraan yang masuk ke dalam negara dan ada aspek-aspek kenegaraan yang membutuhkan legitimasi agama (Asroni, 2011).

Mengacu pada landasan pemahaman di atas maka adanya gerakan politikIslam GNPFUlama dalam pilpres 2019 merupakan perwujudan dari civil Islam dalam menyikapi perkembangan politik nasional. Bentuk gerakan yang dilakukan diantaranya dengan menyelenggarakan Ijtima ulama pertama pada 27-29 Juli 2018, tujuannya untuk memberikan rekomendasi calon wakil presiden bagi Prabowo Subianto. Nama Prabowo Subianto mencuat, karena saat itu menurut survey, Prabowo Subianto memiliki tingkat elektabilitas yang hampir mendekati elektabilitas calon presiden incumbent, yaitu Joko Widodo.

Hasil dari Ijtima pertama adalah mengusulkan dan mendorong dibentuknya sebuah koalisi di antara partai-partai politik pengusung calon presiden dengan nama Koalisi Keumatan yaitu Partai Gerakan Indonesia Raya, Partai Keadilan Sejahtera, Partai Amanat Nasional, Partai Bulan Bintang. Lebih lanjut Yusuf Muhammad Martak menjelaskan bahwa partai-partai yang diajak untuk bergabung adalah yang tidak berkoalisi dengan calon incumbent. Partai partai tersebut menjadi satu koalisi dengan keumatan, dengan GNPF- Ulama, FPI, dan PA 212, serta ormas-ormas Islam yang lain (Purnomo, 2019). 
Ijtima Ulama yang pertama juga memberikan rekomendasi calon wakil presiden bagi Prabowo Subianto. Kriteria yang diajukan bagi Prabowo Subianto adalah calon wakil presiden yang memiliki latar belakang agama. Calon yang direkomendasikan dalam Ijtima Ulama tersebut ada dua, yakni Ketua Majelis Syuro PKS, Salim Segaf Al-Jufri dan seorang pemuka agama yang sedang naik daun yaitu Ustaz Abdul Somad Batubara. Alasan Ijtima mengusulkan calon wakil presiden dengan latar belakang ulama, karena periode pemerintahan yang pertama, sudah mulai bergeser jauh dengan kemaslahatan umat Islam (Purnomo, 2019).

Prabowo Subianto akhirnya memutuskan untuk memilih Wakil Gubernur provinsi DKI Jakarta, yang juga merupakan kader partainya sendiri, Partai Gerakan Indonesia Raya, yakni Sandiaga Salahuddin Uno sebagai pendampingnya menjadi calon wakil presiden pada pilpres tahun 2019, dan tidak memilih dua nama yang telah diputuskan oleh GNPF-Ulama.

Terkait dengan koalisi Keumatan, Ketua Dewan Pembina GNPF-Ulama Habib Rizieq Shihab setelah mengadakan pertemuan dengan tokoh PA 212, dan elite koalisi penantang petahana di Mekkah pada tanggal 2 Juni 2018, mengatakan untuk perlunya meningkatkan komunikasi empat parpol menjelang pilpres tahun 2019, yang diharapkan dapat membentuk Koalisi Keumatan (Seputro, 2019).

Kemudian, dengan dipilihnya Sandiaga Uno sebagai Cawapres, penasihat PA 212, Eggi Sudjana mengatakan ketika pasangan Prabowo Subianto dan Sandiaga Uno resmi diumumkan, GNPF belum mengambil sikap resmi. Namun, ia mengaku dipilihnya Sandiaga Salahuddin Uno sudah dikomunikasikan antara Amien Rais dengan Habib Rizieq Shihab (Budiatri et al., 2018).

Mengenai Pakta Integritas dan dukungan kepada Prabowo Subianto-Sandiaga Uno, dalam konferensi pers, Ketua UmumGNPF-Ulama Yusuf Martak mengatakan telah terlaksana dengan baik Ijtima Ulama II dan ditandatanganinya Pakta Integritas oleh Prabowo Subianto dan Sandiaga Salahuddin Uno. forum Ijtima Ulama II memutuskan mendukung Prabowo Subianto dan Sandiaga Salahuddin Uno untuk bertarung di pilpres tahun 2019 (Pratiwi, 2018). Dalam rangka kegiatan kampanye dan sosialisasi untuk pasangan Prabowo Subianto- Sandiaga Salahuddin Uno, GNPF-Ulama bekerjasama dengan berbagai pihak, dengan Persaudaraan Alumni 212, FPI, dan ormas-ormas Islam yang lain. Dalam kegiatan kampanye, GNPF-Ulama hampir selalu jalan bersama dengan ketua umum Persaudaraan Alumni 212, Ustaz Slamet Maeearif. Dalam hal ini pula, GNPF-Ulama selalu koordinasi dengan Habib Rizieq Shihab, sebagai Ketua Dewan Pembina GNPF-Ulama (Purnomo, 2019).

Maarif menjelaskan bahwa dalam hal sosialisasi, kampanye, tidak ada koordinasi, tidak ada bimbingan, apalagi logistik, karena tidak pernah mengajukan, karena tidak ada inisiatif untuk mendiskusikan hal ini. Menurutnya kami bisa menerima itu semua, namun karena kami punya kepentingan lebih besar, maka kami berjuang masing-masing dengan segala tenaga, pikiran, materi, tanpa ada komunikasi tentang itu semua (Maarif \& Matin, 2019).

Lebih jauh Maarif menjelaskan bahwa dalam seluruh bentuk gerakan politik, GNPFUlama dan PA 212, tidak dapat diintervensi siapapun, termasuk oleh partai politik dengan landasan sebagai sayap juang dari rakyat. Dalam pilpres 2019 ini, GNPF-Ulama dan PA 212 melakukan kerjasama dengan partai politik, karena merupakan perhelatan politik. Kemudian terkait dengan Persaudaraan Alumni 212, Maarif menjelaskan bahwa PA 212 adalah sayap juang daripada GNPF-Ulama, yang didirikan oleh Habib Rizieq Shihab. Alasannya karena Persaudaraan Alumni 212 sudah bisa membuktikan prestasinya, kerjanya, melalui koordinasi dan kekompakkannya dengan semua pihak, sehingga telah menjadi sebuah organisasi yang cukup diperhitungkan (Maarif \& Matin, 2019).

Maarif menjelaskan bahwa dalam hal sosialisasi, kampanye, tidak ada koordinasi, tidak ada bimbingan, apalagi logistik, karena tidak pernah mengajukan, karena tidak ada inisiatif untuk mendiskusikan hal ini. Menurutnya kami bisa menerima itu semua, namun karena kami punya kepentingan lebih besar, maka kami berjuang masing-masing dengan segala tenaga, 
pikiran, materi, tanpa ada komunikasi tentang itu semua (Maarif \& Matin, 2019).

Lebih jauh Maarif menjelaskan bahwa dalam seluruh bentuk gerakan politik, GNPFUlama dan PA 212, tidak dapat diintervensi siapapun, termasuk oleh partai politik dengan landasan sebagai sayap juang dari rakyat. Dalam pilpres 2019 ini, GNPF-Ulama dan PA 212 melakukan kerjasama dengan partai politik, karena merupakan perhelatan politik. Kemudian terkait dengan Persaudaraan Alumni 212, Maarif menjelaskan bahwa PA 212 adalah sayap juang daripada GNPF-Ulama, yang didirikan oleh Habib Rizieq Shihab. Alasannya karena Persaudaraan Alumni 212 sudah bisa membuktikan prestasinya, kerjanya, melalui koordinasi dan kekompakkannya dengan semua pihak, sehingga telah menjadi sebuah organisasi yang cukup diperhitungkan (Maarif \& Matin, 2019).

\section{Pengaruh Gerakan Politik Islam GNPF-Ulama dalam Mendukung Prabowo Subianto dan Sandiaga Salahuddin Uno}

Sebagai sebuah wadah perjuangan yang sedari awal menaruh kekecewaan terhadap pemerintahan sebelumnya, GNPF-Ulama melakukan segala cara agar dapat mengakomodir keinginan umat untuk dapat memperoleh pemimpin nasional yang diharapkan, termasuk dengan menggelar serangkaian diskusi politik untuk membicarakan hal-hal mengenai kemaslahatan umat.

Digelarnya Ijtima Ulama I oleh GNPF-Ulama adalah dalam rangka memberikan usulan dan saran-saran mengenai calon wakil presiden yang layak untuk mendampingi calon presiden Prabowo Subianto. Pada keputusan forum tersebut, diusulkanlah dua orang tokoh yang memiliki latar belakang dari kalangan agamis, yaitu pertama Ketua Majelis Syuro PKS, Salim Segaf Al Jufri, dan kedua adalah Ustaz Abdul Somad Batubara.

Dalam forum Ijtima Ulama I tersebut pula, dirancang sebuah gagasan mengenai koalisi yang terdiri dari gabungan partai-partai politik, yang tidak berada dalam koalisi pendukung pemerintah, dengan nama Koalisi Keumatan. Dengan harapan, agar dengan koalisi tersebut, kekuatan umat dapat lebih solid sehingga dapat memenangi kontestasi melawan calon presiden petahana, Joko Widodo dalam pilpres 2019.

Aksi Bela Islam bagi kelompok GNPF-Ulama, awalnya mereka berharap gerakan tersebut berpengaruhsetidaknya menjangkau seluruh lapisan masyarakat secara nasional, namun ternyata dalam aksi tersebut tidak berpengaruh secara signifikan, karena hasil pemilu nasional tidak menunjukkan itu. Pengaruh gerakan politik GNPF-Ulama di tingkat lokal diantaranya Aceh, Sumatera Barat, NTB dan sebagian di Jawa Barat (Purnomo, 2019).

Kenyataannya,seluruh gerakan perjuangan dari GNPF-Ulama, yang diawali dengan Ijtima Ulama yang pertama tidak berjalan dengan mulus. Hal ini dikarenakan sejak awal, salah satu calon yang diusulkan yaitu Ustaz Abdul Somad Batubara menyatakan sedari awal tidak bersedia untuk dicalonkan sebagai calon wakil presiden, dan sosok Salim Segaf Al Jufri tidak begitu disepakati dalam tubuh koalisi, dengan pertimbangan kepartaian. Namun, diakui oleh Ketua Umum Persaudaraan Alumni 212, Slamet Maeearif bahwa nama Ustaz Abdul Somad Batubara yang diusulkan oleh Ijtima Ulama yang pertama, sesungguhnya sudah disambut baik oleh Prabowo Subianto. Namun, Ustaz Abdul Somad Batubara sendiri yang tidak bersedia sejak awal dicalonkan. Dalam hal ini dapat dilihat bahwa, GNPF-Ulama tidak mampu membangun sebuah komunikasi dan lobi-lobi yang matang dan mengkomunikasikannya dengan intens terhadap partai-partai politik di koalisi terkait dengan penentuan calon wakil presiden tersebut (Purnomo, 2019).

Hal tersebut senada dengan pernyataan Efriza (2019) yang menilai bahwa Prabowo merasa rekomendasi Ijtima Ulama hanya sebagai saran. Prabowo sendiri bahkan sudah mengingkari sejak awal tahapan proses pencalonan (dari GNPF-Ulama) dan kemudian memperkenalkan Sandiaga Salahudin Uno. GNPF-Ulama dari awal tidak mampu mempengaruhi Prabowo Subianto, apalagi kemudian untuk mempengaruhi masyarakat pemilih yang lebih luas (Purnomo, 2019). 
Terkait usulan calon wakil presiden pada forum Ijtima Ulama yang pertama, diakui oleh Ketua Umum GNPF-Ulama, Ustaz Yusuf Muhammad Martak, tidak ditemukan kata kesepakatan antar partai politik pengusung Prabowo Subianto. Lebih jauh Martak menjelaskan bahwa saat itu satu nama pun tidak pernah muncul, maka diinisiatifkan di dalam Ijtima. Karena partai-partai politik dalam koalisi ini tidak bisa menyelesaikan masalahnya masing-masing. Dalam hal ini, partai politik mempunyai dilema dalam menentukan calon wakil presiden, karena mereka semua merasa berhak untuk mendapatkan posisi tersebut (Purnomo, 2019).

Mengenai gagasan tentang Koalisi Keumatan yang diusulkan oleh Habib Rizieq Shihab dan diteruskan ke dalam forum Ijtima Ulama, juga tidak dapat direalisasikan sebagaimana rencana awal. Perjalanan koalisi tersebut mengalami dinamika yang cukup signifikan dalam hal kesolidan politik terhadap pasangan Prabowo Subianto dan Sandiaga Salahuddin Uno. Adanya tambahan dari partai-politik di samping menambah kekuatan, pada sisi lain juga mereduksi label keumatan yang dicanangkan sejak awal.

Tidak kokohnya Koalisi Keumatan diakui pula oleh Ketua Umum PA 212, Slamet Maearif yang mengatakan bahwa eksistensi partai koalisi keumatan di daerah saat pilkada sudah mulai goyah. Kemudian di pilpres pun, kita mengawal, supaya tiga partai ini tidak terpecahkan. Pada akhirnya ternyata tiga partai ini berkembang, masuk Partai Berkarya, masuk Partai Demokrat, yang pada akhirnya tidak semua yang baru masuk, sepakat dengan nama "keumatan", maka dari itu koalisi keumatan ini berubah, ketika dibentuk Badan Pemenangan Nasional (BPN), menjadi Koalisi Indonesia Adil dan Makmur (Maarif \& Matin, 2019).

(Budiatri et al., 2019) menilai koalisi keumatan sudah tenggelam dari awal, dan sulit juga untuk membuat Koalisi Keumatan. Karena, satu-satunya partai Islam hanya Partai Keadilan Sejahtera (PKS). Pada sisi lain, Partai Gerindra merupakan partai nasionalis. Partai Demokrat juga, meskipun taglinenya Nasionalis-Religius, namun sangat kental nasionalis dibandingkan religiusnya. Partai Amanat Nasional (PAN) dapat dianggap partai Islam, namun PAN lebih kepada partai nasionalis yang berbasis massa Islam, massa Muhammadiyah, faktanya memang partai nasionalis. Jadi akhirnya keberadaan partai-partai tersebut tidak bisa menambah kekuatan, karena anggota koalisinya heterogen. Partai Gerindra, Partai Demokrat, Partai Amanat Nasional itu partai nasionalis, partai Islam yang berbasis massa Islam itu hanya Partai Keadilan Sejahtera (Budiarti, 2017).

\section{Gerakan Politik GNPF-Ulama dalam Menyikapi Kekalahan Prabowo Subianto dan Sandiaga Salahuddin Uno}

Dengan melihat gerakan politik GNPF-Ulama yang tidak dapat memberikan pengaruh secara signifikan, kurang berpadunya kekuatan partai pengusung dengan persoalan internalnya masing-masing dan berbagai persoalan lainnya yang terjadi sejak awal dalam tim pemenangan pasangan Prabowo Subianto dan Sandiaga Salahuddin Uno, kekalahan bagi pasangan tersebut menjadi hal yang tidak dapat terelakkan lagi.

Komisi Pemilihan Umum akhirnya mengumumkan secara resmi hasil perolehan suara pada pilpres 2019 dengan kemenangan untuk pasangan calon presiden petahana Joko WidodoK. H. Ma'ruf Amin dengan perolehan angka sebesar 55,50\% dengan jumlah suara sebesar 85.607.362 suara dan Prabowo Subianto-Sandiaga Salahuddin Uno sebesar 44,50\% dengan jumlah suara sebesar 68.850.239 suara.

Pihak Prabowo Subianto-Sandiaga Salahuddin Uno tidak menerima hasil KPU tersebut dan mengklaim memiliki hasil penghitungan sendiri yang menyatakan pihaknya menang. Dengan kekalahan pasangan tersebut, para tokoh Islam yang berada dalam GNPF- Ulama beserta massa dari FPI, dan aktivis 212 juga tidak dapat menerimanya dan mereka bersama menyatakan bahwa kemenangan pasangan petahana tersebut adalah hasil kecurangan yang terjadi secara terstruktur, sistematis, dan massif.

Pasangan Prabowo Subianto-Sandiaga Salahuddin Uno memutuskan untuk membawa sengketa pilpres ke Mahkamah Konstitusi, pihak GNPF-Ulama dan juga PA 212 dan sejumlah 
organisasi lain menggelar aksi mengawal sidang di Mahkamah Konstitusi yang dilangsungkan pada tanggal 28 Juni 2019. Mereka menyatakan aksi yang akan digelar di sekitar gedung Mahkamah Konstitusi itu akan berlangsung damai.

Akhirnya Mahkamah Konstitusi (MK) menolak seluruh permohonan gugatan hasil Pilpres 2019 yang diajukan Prabowo Subianto-Sandiaga Salahuddin Uno. Dengan putusan ini, pasangan Joko Widodo-Ma'ruf Amin tetap memenangi Pilpres 2019. Mahkamah Konstitusi (MK) menyatakan penanganan pelanggaran administratif yang bersifat terstruktur, sistematis, dan masif dalam pemilu merupakan kewenangan Bawaslu. Dalam putusannya, MK menolak semua dalil permohonan Prabowo-Sandiaga. MK menilai dalil yang diajukan tidak beralasan menurut hukum karena pemohon tidak bisa membuktikan dalil permohonannya dan hubungannya dengan perolehan suara (Budhiati, 2020).

Hasil Pilpres 2019, sangat mengecewakan bagi pasangan Prabowo Subianto dan Sandiaga Salahuddin Uno, lebih khusus lagi terhadap GNPF-Ulama, serta kelompokkelompok Islam lainnya seperti PA 212, yang telah bergerak dan berjuang sejak awal mendukung pasangan tersebut untuk dapat memenangi pilpres, ditambah lagi dengan ditolaknya gugatan sengketa pilpres terkait tuduhan kecurangan dan kemenangan pasangan tersebut oleh Mahkamah Konstitusi.

Menyikapi keputusan MK, GNPF-Ulama mengadakan Ijtima Ulama ketiga 5 Agustus 2019, di Hotel Lor In, Sentul, Bogor. Forum tersebut menghasilkan berbagai keputusan dan rekomendasi terkait proses-proses yang terjadi selama pemilu berlangsung yang dimaksudkan kepada pasangan 02, bahwa telah terjadi berbagai kecurangan selama proses pemilu. Bahkan dalam forum tersebut, mendesak bawaslu dan KPU untuk mendiskualifikasi pasangan calon Joko Widodo - K. H. Maeruf Amin.

GNPF-Ulama dan Prabowo Subianto-Sandiaga Salahuddin Uno bukan kalah, tapi dikalahkan. Menurutnya, mereka mempunyai keyakinan, karena mempunyai bukti-bukti mengenai kecurangan secara sistematis. Kemudian, Maarif menekankan bahwa bagi GNPFUlama pilpres sudah selesai. Artinya GNPF-Ulama kembali kepada gerakan moral, untuk menegakkan keadilan (Maarif \& Matin, 2019).

Akhirnya pasangan Prabowo Subianto dan Sandiaga Salahuddin Uno dinyatakan kalah oleh KPU, pendukung pasangan nomor urut 02, GNPF-Ulama dan termasuk kelompok dari kalangan Islam yang menjadi pendukung pasangan tersebut sangat kecewa, dan tidak dapat menerima kekalahan tersebut.

Pasca menyelenggarakan Ijtima Ulama ketiga dan memutuskan hasil-hasilnya, terkait asumsi kecurangan, dan setelah itu pula terdapat aksi-aksi unjuk rasa di gedung Badan Pengawas Pemilu. Setelah menyelenggarakan Ijtima Ulama yang ketiga, GNPF-Ulama kembali mengadakan Ijtima Ulama yang keempat. Forum yang diadakan pada 5 Agustus 2019 tersebut kembali diselenggarakan di Hotel Lor In, Sentul, Bogor, Jawa Barat. Dalam kesempatan tersebut, GNPF-Ulama kembali mengeluarkan beberapa keputusan yang dirumuskan dan disepakati oleh para ulama yang hadir.

Ijtima Ulama keempat bertujuan menyikapi hasil Ijtima Ulama ketiga. Di Ijtima Ulama III sudah memutuskan, bahwa pemilu Presiden 2019 penuh dengan kecurangan secara sistematis, terstruktur, melibatkan aparat, kemudian instansi pemerintah terlibat. Ijtima Ulama keempat menekan beberapa poin, salah satunya yaitu GNPF-Ulama, serta PA 212 dan seluruh ormas Islam lainnya menjaga jarak dengan pemerintah (Maarif \& Matin, 2019).

\section{Kesimpulan}

Populisme gerakan politik Islam yang terjadi dalam pilkada DKI Jakarta tahun 2017 dan berlanjut dalam perhelatan pemilu presiden (Pilpres) tahun 2019, memunculkan beberapa peristiwa-peristiwa dalam politik yang bergesekan cukup keras dengan isu-isu terkait dengan 
sentimen identitas, terlebih lagi dengan persoalan agama. Hal tersebut memiliki dampak yang luas terhadap polarisasi masyarakat, sehingga memunculkan kelompok-kelompok kepentingan yang menginginkan perubahan secara menyeluruh dalam seluruh aspek kehidupan masyarakat Indonesia.

Kehadiran kelompok-kelompok kepentingan dalam kontestasi pemilihan umum presiden (Pilpres) merupakan satu hal yang sangat lumrah. Kehadiran gerakan politik Islam GNPFUlama menjadi salah satu contohnya. Dengan latar belakang memperjuangkan kepentingan umat Islam, mereka bergerak dalam perjuangan untuk memperoleh pemimpin nasional yang mereka inginkan. Dalam perjalanannya, perjuangan gerakan politik Islam GNPF-Ulama dihadapkan kepada kenyataan empiris bahwa konstelasi politik menjelang dan sesudah Pilpres 2019 sangat dinamis dan menentukan serta berpengaruh secara langsung maupun tidak langsung terhadap setiap gerakan politik yang mereka lancarka.

Gerakan politik yang diperjuangkan oleh GNPF-Ulama, yang didukung oleh kelompok Islam lainnya, banyak menemui hambatan dan berbagai kesulitan. Tidak hanya karena faktor konstelasi politik, sebagai sebuah organisasi masyarakat yang secara momentum bekerjasama dengan organisasi politik, kalangan ulama yang berada di GNPF- Ulama tidak memiliki basis massa yang kuat dan jaringan akar rumput yang memadai untuk memenangkan pasangan Prabowo Subianto-Sandiaga Salahuddin Uno. 


\section{Bibliografi}

Abdillah, M. (2013). Hubungan agama dan negara dalam konteks modernisasi politik di era reformasi. AHKAM: Jurnal Ilmu Syariah, 13(2).

Abdullah, A. (2018). Membaca Komunikasi Politik Gerakan Aksi Bela Islam 212: Antara Politik Identitas dan Ijtihad Politik Alternatif. An-Nida', 41(2), 202-212.

Aly, S. (2018). Pemikiran politik islam (sejarah, praktik dan gagasan). PT. Rajagrafindo Persada.

Asroni, A. (2011). Pemikiran Ahmad Syafii Maarif tentang Negara dan Syariat Islam di Indonesia. Millah: Jurnal Studi Agama, 10(2).

Budhiati, I. (2020). Mahkamah Konstitusi dan Kepastian Hukum Pemilu: Tafsir Mahkamah Konstitusi Terhadap UUD NRI Tahun 1945 untuk Kepastian Hukum Pemilu. Sinar Grafika.

Budiarti, C. (2017). Pengaruh Teknik Sterilisasi dan Zat Pengatur Tumbuh 2, 4-D (2, 4 Dikloro Fenoksiasetat), BAP (Benzil Amino Purin) terhadap Induksi Kalus Nilam (Pogostemon cablin Benth) Secara In Vitro. UIN Sunan Gunung Djati Bandung.

Budiatri, A. P., Haris, S., Romli, L., Nuryanti, S., Nurhasim, M., Amalia, L. S., Darmawan, D., \& Hanafi, R. I. (2018). Personalisasi partai politik di Indonesia era reformasi. Yayasan Pustaka Obor Indonesia.

Budiatri, A. P., Mengko, D. M., Noor, F., Gayatri, I. H., Nurhasim, M., Haripin, M., Dewi, K. H., Romli, L., Amalia, L. S., \& Hanafi, R. I. (2019). Menimbang demokrasi dua dekade reformasi. Yayasan Pustaka Obor Indonesia.

Creswell, J. W., \& Creswell, J. D. (2017). Research design: Qualitative, quantitative, and mixed methods approaches. Sage publications.

Efriza, E. (2019). Penguatan Sistem Presidensial Dalam Pemilu Serentak 2019. Jurnal Penelitian Politik, 16(1), 1-15.

Hasan, N. (2007). „Islam politik, teori gerakan sosial, dan pencarian model pengkajian Islam baru. Al-Jami'ah: Journal of Islamic Studies.

Jamaan, A., \& Wijaksono, A. (2014). Gerakan Politik Islam Hizbut Tahrir Di Indonesia Pada Era Pasca Reformasi. Riau University.

Jayanto, D. D. (2019). Mempertimbangkan Fenomena Populisme Islam di Indonesia dalam Perspektif Pertarungan Diskursif: Kontestasi Wacana Politik Antara Gerakan Nasional Pengawal Fatwa Ulama (GNPF-Ulama) dan Nahdlatul Ulama (NU). Jurnal Filsafat, 29(1), 1-25.

Maarif, N. N., \& Matin, U. A. (2019). Wakaf: Kajian Komunikasi Yang Memotivasi Umat Untuk Berwakaf. Jurnal Indo-Islamika, 9(1), 115-138. 
Sandy Anugrah Tangkas, Indiana Ngenget dan Musthofa

Mayrudin, Y. M. (2018). Diskursus Demokratisasi Indonesia Pasca Orde Baru. Jurnal Polinter: Kajian Politik Dan Hubungan Internasional, 3(2).

Muhtadi, B. (2019). Populisme, politik identitas, dan dinamika elektoral: mengurai jalan panjang demokrasi prosedural. Intrans Publishing.

Mujani, S. (2007). Muslim demokrat: Islam, budaya demokrasi, dan partisipasi politik di Indonesia pasca Orde Baru. Gramedia Pustaka Utama.

Ngenget, I. (n.d.). Kebangkitan Islam Politik: Analisis Gerakan Aksi Bela Islam Dalam Pilkada DKI Jakarta 2017.

Pratiwi, S. (2018). Konstruksi Pemberitaan Gerakan\# 2019GantiPresiden (Analisis Framing Robert $N$ Entman pada Kompas. com dan Detik. com). Universitas Islam Negeri Alauddin Makassar.

Purnomo, M. (2019). Ijtima Ulama Simbolis Gerakan Nasional Pengawal Fatwa Ulama (GNPF-U) pada Pemilihan Presiden Tahun 2019. UIN Sunan Ampel Surabaya.

Sari, E. (2016). Kebangkitan Politik Identitas Islam Pada Arena Pemilihan Gubernur Jakarta.

KRITIS: Jurnal Ilmu Sosial Dan Ilmu Politik Universitas Hasanuddin, 1(1), 145-156.

Seputro, A. (2019). Manajemen Strategik Pemberdayaan Ekonomi UMKM Bagi Masyarakat Menengah Kebawah dalam Rangka Menangkal Paham Radikalisme dan Terorisme di Era Revolusi Industri 4.0. Jurnal Ekonomi Dan Bisnis Kontemporer, 5(2).

Sholikin, A. (2018). Gerakan Politik Islam di Indonesia Pasca Aksi Bela Islam Jilid I, II dan

III. Madani, 10(1).

Sugiyono. (2012). Metode Penelitian Kuantitatif, Kualitatif dan R \& D.Bandung:Alfabeta. Metode Penelitian Kuantitatif, Kualitatif Dan $R \quad \& \quad$ D.Bandung:Alfabeta. https://doi.org/10.1017/CBO9781107415324.004

Tansal, E. A. (2019). Representasi Politik Identitas dalam Pemberitaan Pemilihan Presiden 2019 pada Kompas. com (Analisis Framing Robert $N$ Entman). Universitas Islam NegeriAlauddin Makassar.

Walidin, W., \& Idris, S. (2015). Metodologi Penelitian Kualitatif \& Grounded Theory. FTK Ar-Raniry Press. 